\title{
FELINE CORNEAL SEQUESTRATION
}

\section{SEQÜESTRAÇÃO CORNEANA DOS FELINOS}

\author{
Arianne Pontes Oriá ${ }^{1}$ Ana Maria Barros Soares ${ }^{2}$ José Luiz Laus $^{3}$ \\ Francisco de Assis Dórea Neto ${ }^{4}$
}

\section{- REVIEW ARTICLE -}

\section{SUMMARY}

Corneal sequestration is a disease unique to domestic cats, clinically characterized by chronicity; signs of ocular pain with the development of a dark brown to black, opaque, oval, paracentral or central corneal plaque. The purpose of this review article was to approach and discuss about the etiology, clinical manifestations, diagnosis, and treatment of the corneal sequestrum.

Key words: cats, corneal diseases, corneal sequestration, keratitis, ulcer.

\section{RESUMO}

Seqüestro corneano é uma doença única dos gatos domésticos. Caracterizada clinicamente pela crônicidade, sinais de dor ocular, com desenvolvimento de placa marrom a enegrecida, opaca, de localização central ou paracentral. O propósito deste artigo de revisão é abordar e discutir questões sobre a etiologia, manifestações clínicas, diagnóstico e tratamento da enfermidade.

Palavras-chave: gatos, doenças corneanas, seqüestro corneano, ceratites, úlcera.

\section{INTRODUCTION}

Corneal sequestration is a dramatic and unusual corneal disease unique to domestic cats.
This condition has been described in the literature since 1960s (PENTLARGE, 1996). Also called corneal mummification, corneal nigrum, corneal necrosis and necrotizing keratitis, the central or paracentral corneal stroma undergoes coagulation necrosis, which appears as a brown-black plaque (MORGAN, 1994).

\section{ETIOLOGY}

The exact etiology of corneal sequestrum has not been determined. The process in the feline cornea may be a response to a variety of problems (WHITLEY et al., 1993). Early reports suggested that corneal trauma from ulceration, entropion, trichiasis, or exposure to caustic chemicals, could precipitate the corneal stromal necrosis (MORGAN, 1994). In addition PENTLARGE (1996) referredgenetics, tear-film composition, a primary corneal stromal metabolic or neurologic disturbance, or an infective agent may singly or in combination play a role. ZIGLER (1999) suggested that feline sequestrum may occurs whenever there is an irritation or chronic damage of the corneal stroma.

\footnotetext{
${ }^{1}$ Graduate Student, Ophthalmology Unit, Veterinary College, São Paulo State University (UNESP).

${ }^{2}$ Assistent Professor, MS, Federal Fluminense University; Graduate Student, Ophtalmology Unit, Veterinary College, São Paulo State University (UNESP).

${ }^{3}$ Associate Professor, DVM, PhD., Ophthalmology Unit Veterinary College, São Paulo State University (UNESP), Via de Acesso Prof. Paulo Donato Castellane, Km5, 14884-900, Jaboticabal, SP - Brazil. E-mail: jllaus@ fcav.unesp.br.

${ }^{4}$ Graduate Student, Surgery Section, Veterinary College, São Paulo State University (UNESP). 
Several studies were conducted in an attempt to discover the origin of the lesions. DAVIDSON et al. (1992) determined the protein concentrations and their molecular weight, using the Bradford technique, in tears from cats with normal corneas and cats with corneal sequestrum. They did not find detectable difference in the band patterns for the two groups. EJIMA et al. (1993) analyzed a blackish lesion removed from a cat with severe corneal sequestration and identified iron in it. Results of chemical analysis indicated that the iron was not derived from blood in the neovascularized limbus.

Corneal sequestration has been described in all breeds of cats but it is more common in the Persian breed followed by the Siamese, Burmese, Himalayan, and domestic short hair breeds (PENTLARGE, 1996; GLAZE \& GELATT, 1999). The predilection for certain breeds has promoted the speculation regarding a hereditary basis, and the condition has also been suggested to be a type of dystrophy (GLAZE \& GELATT, 1999).

NASISSE (1998b) suggested that it is probably a nonspecific response to insult, seen more commonly in brachycephalic cats with exposure keratitis, and also occurs secondary to herpetic keratitis (NASISSE, 1998b).

STILES $\boldsymbol{e t}$ al. (1997) described the use of nested polymerase chain reaction (PCR) to detect feline herpesvirus 1 (FHV-1) DNA in ocular specimens from cats with sequestrum and from clinically normal cats. PCR was positive in 5 of 28 (18\%) corneal specimens from cats with sequestrum and 6 of $13(46 \%)$ clinically normal cats. The distribution of positive results was considered not significant. They suggested that FHV-1 might be less of a cause of the disease in commonly affected breeds like Himalayan and Persian, than other factors, such as corneal metabolic defects and lagophthalmos.

NASISSE $\boldsymbol{e}$ t $\boldsymbol{a l}$. (1998) by using PCR, obtained different results. They detected FHV-1 in $5.9 \%(1 / 17)$ of corneas from clinically normal cats and in $55.1 \%(86 / 156)$ from specimens from cats with corneal sequestra. Their data strongly implied the involvement of FHV-1 in the pathogenesis of the disease. However were similar to the suggestion made by STILES et al. (1997) concerning breed predisposition. Prevalence of FHV-1 DNA was significantly lower in Persian and Himalayan, compared with domestic shorthair and longhair breeds. At the same year NASISSE (1998a) considered that sequestration is a non-specific response to the substantial stromal damage done by
FHV-1 under these conditions, and not the only cause of corneal sequestration.

\section{CLINICAL MANIFESTATIONS}

The lesion is usually in the central or paracentral cornea, circular or oval in shape, and it contains invariably pigments. Degeneration of collagen and accumulation of a brown pigment (GLAZE \& GELATT, 1999) characterize it (Figure1). The sequestrum most often affects the anterior third of the corneal stroma but can extend to descemet's membrane in some cases. With chronicity, the sequestration becomes denser, and the edges may begin to separate from the adjacent corneal stroma. In addition, corneal neovascularization and perilesional edema occur (WILKIE, 1994) (Figure2).

Affected cats may exhibit blepharospasm, lacrimation, enophtalmos, elevation of the nictitating membrane, and decreased activity and appetite that reflect the painful nature of the disease (PENTLARGE, 1996).

\section{DIAGNOSIS}

Topical fluorescein stain usually is not retained; however, rose bengal stain may be retained by the degenerating epithelium (WHITLEY et al., 1993). The intraocular structures of affected eyes are usually normal (PENTLARGE, 1996).

The characteristic histopathologic finding in sequestra is coagulation necrosis of the corneal stroma (PENTLARGE, 1996). It reveals degenerative collagen and fibroblasts, with a surrounding zone of inflammatory cells that

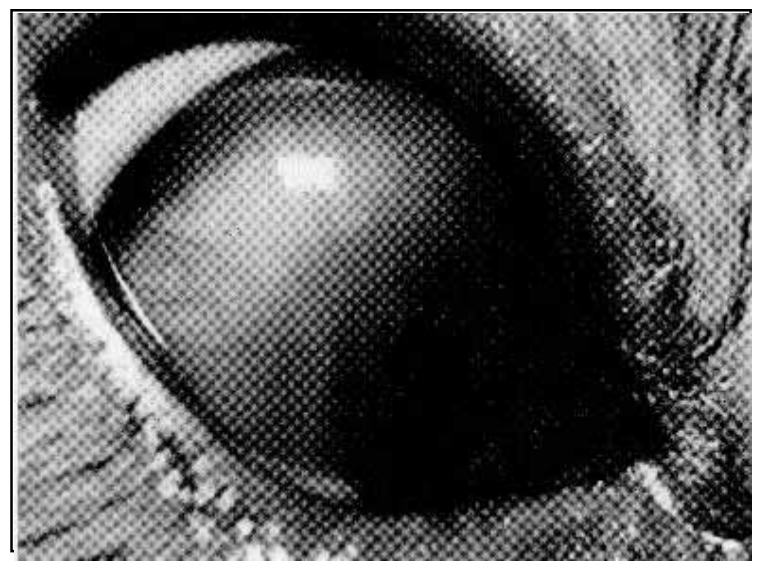

Figure 1 - Corneal sequestrum in a Persian cat, associated with intense corneal vascularization. 


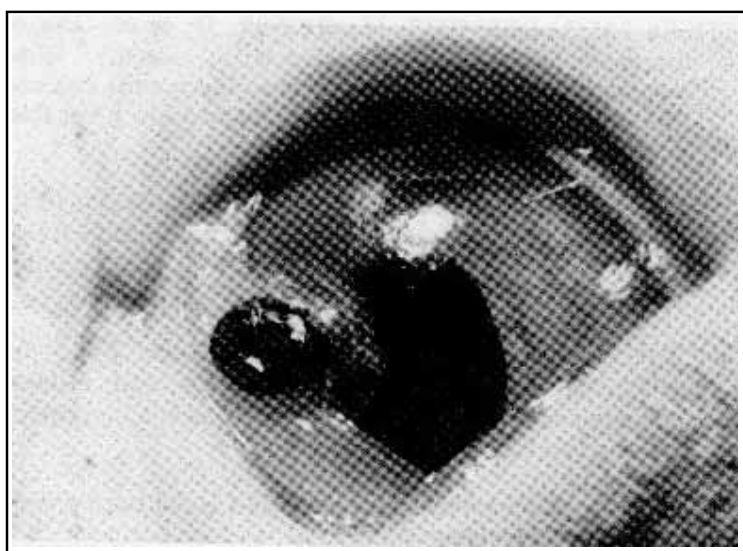

Figure 2 - A dark brown corneal sequestrum in a Mixed breed cat, is present in the paracentral cornea, surrounded by an edematous epithelium.

included lymphocytes, plasma cells, macrophages, and less commonly, polymorphonuclear leukocytes, macrophages, and giant cells (GLAZE \& GELATT, 1999).

\section{TREATMENT}

Several therapeutic options, which can be individually choused, are available to the clinician for the management of cats with corneal sequestration (PENTLARGE, 1996).

An effort is first made to identify and correct any underlying causes (GLAZE \& GELATT, 1999). Particular attention should be focused on eyelid conformation and function, corneal sensation, conjunctival membranes, aberrant hair growth, and tear production (PENTLARGE, 1996).

Medical therapy is designed to encourage vascular ingrowth to accelerate the sloughing process (MURPHY, 1992). Topical antibiotics are indicated for concurrent corneal ulceration and provide lubrications if tear production is reduced (KITRSCHNER, 1992).

If the sequestrum is associated with herpesvirus infection, the eyes should be topically treated with antiviral drugs (NASISSE, 1998b). MURPHY (1992) usually pursue medical therapy for a period of 1 to 2 weeks in order to assess more carefully the probablity that medical therapy will bring about a final resolution of the sequestrum. Although corneal sequestration may resolve with medical therapy alone, healing times are much longer than for those achieved with superficial keratectomy (MORGAN, 1994). SLATTER (1990) pointed out that cats with severe pain from the condition should not be subjected to pain, which is often severe, waiting for the necrotic tissue to come off.
Stromal keratectomy is an effective therapeutic alternative, and most lesions are healed within four weeks (MORGAN, 1994). In cases where superficial keratectomies are performed postsurgical procedures such as use of a hydrophilic soft contact lens, and nictitating membrane flaps are indicated. (PENTLANGE, 1996).

For deep lamellar keratectomies conjunctival grafts are used to provide a better corneal support (PENTLARGE, 1996; NASISSE, 1998b).

\section{CONCLUSION}

Clinical management does not resolve the disease process. In the authors opinion it's not worth waiting for the necrotic tissue to come off. Superficial lamellar keratectomy with nictitating membrane flap seems to be suitable for the many cases presented, which is a good option in the absence of adequate instruments for more sophisticated techniques. Otherwise when deep keratectomies are necessary, a conjunctival graft is important to provide more corneal support, improve the cat's postsurgical comfort, and aid the healing of the cornea.

\section{REFERENCES}

DEVIDSON, H.J., GERLACH, J.A., BULL, R.W Determination of protein concentrations and their molecular weight in tears fro, cats with normal corneas and cats with corneal sequestrum. Am J Vet Res. v.53, n.10, p.1756-1759,1992

EJIMA, H., HARA, N., KAJIGAYA, H. Detection of iron a blackish lasion is a case of feline corneal sequestration. Vet. Med Sci. v.55, n.6, p.1051-1052, 1993.

GLAZE, M.B., GELATT, N.K. Feline ophthalmology. In: GELATT, N.K.. Veterinary ophthalmology. 3.ed. Philadelphia.: Lippincott Williams \& Wilkins, 1998. p.9971052 .

KIRSCHNER, S.E. Diseases of the cornea and sclera. In: MORGAN, R.V. Handbook of small animal practice. 2.ed. Philadelphia.: Saunders, 1992. p.1063-1076.

MORGAN, R.V. Feline corneal sequestration: a retrospective study of 42 cases (1987-1991). J Am Anim Hosp Assoc, v.30, p.24-69,1994.

MURPHY, C.J . Disorders of the cornea and esclera. In: BONAGURA, J.D, KIRK, R.W. Kirk's current veterinary therapy: small animal practice - XI. Philadelphia : Saunders, 1992. p.1101-1111.

NASISSE, M.P. Ocular viral diseases of animals. Magrane basic course in ophthalmology. Madison : University of Wisconsin, 1998a. p.5. 
NASISSE, M.P. Disease of the conjunctiva and cornea. In: THE NORTH AMERICAN VETERINARY CONFERENCE, 1998, Orlando. Proceedings... Orlando : Eastern States Veterinary Association, 1998b. v.12, p. 533-534.

NASISSE, M.P., GLOVER, T.L. MOORE,C.P., et al. Detection of feline herpesvirus 1 DNA in corneas of cats with eosinophilic keratitis or corneal sequestration. Am J Vet Res, v.59, n.7, p.856-8,1998.

PENTLARGE, V.W. Corneal sequestration in cats. In: GLAZE M.B. Ophthalmology in small animal practice. Trenton : Veterinary Learning Systems, 1996. p. 219-225.

SLATTER, D. Fundamentals of veterinary ophthamology. 2.ed. Philadelphia : Saunders, 1990. Cap.11: Cornea and sclera: p.157-303.
STILES J.M.C., DERMOTT, M., BIGSBY, D., et al. Use of nested polymerase chain reaction to identify feline herpesvirus in ocular tissue from clinically normal cats and cats with corneal sequestra or conjunctivitis. Am J Vet Res, v. 58, n.4, p.338-342, 1997.

WHITLEY, R.D., WHITLEY, E.M., MCLAUGHLIN, S.A. Diagnosing and treating disorders of the feline conjunctival and cornea. Vet Med, v.88 n.12 p.11381149, 1993.

WILKIE, D.A. Diseases and surgery of the eye. ln: SHERDING, R.G. The cat diseases and clinical management. 2.ed. New York: : Churchill Livigstone, 1994. p.2011-2046.

ZIGLER, M. Feline herpetic keratitis. Eye Consulting Services. http//www.eyevet.com. 1999.

Ciência Rural, v. 31, n. 3, 2001. 